\title{
Design of Material Composition and Technology Verification for Composite Front End Cabs
}

Sona Rusnakova ${ }^{1}$, Ladislav Fojtl ${ }^{1}$, Milan Zaludek ${ }^{1}$, Vladimir Rusnak ${ }^{2}$

${ }^{1}$ Department of Production Engineering, Faculty of Technology, Tomas Bata University in Zlí. Nad Stranemi 4511, 760 05 Zlín. Czech Republic.E-mail: fojtl@ft.utb.cz, rusnakova@ft.utb.cz, zaludek@ft.utb.cz

${ }^{2}$ Faculty of Metallurgy and Materials Engineering, VŠB-Technical University of Ostrava, 17. listopadu 15,70833 Ostrava-Poruba, Czech Republic. E-mail: vladimir.rusnak@form-composites.com

Presented research paper is focused on the development of train front end cab, specifically on choice of material composition and production technology. Experimental part deals with a selection of the most appropriate multiaxial fabric based on its saturation by resin and type of polyester resin most suitable for low-pressure vacuum infusion. This technology is chosen with respect to dimensions of the part, resin savings (compared to hand lay-up technology) and also production cost of the cab. Prepared samples are evaluated regarding to the progress of production technology, part face quality (voids, dry spots, and delamination) and technological properties. As a result, optimal material composition for front end cab production is chosen and fabrication of prototype cab is conducted.

Keywords: Train Cab, Vacuum Infusion, Fiberglass Composite, Multiaxial Fabric, Polyeste r Resin

\section{Acknowledgement}

This work and the project is realized with the financial support of the Ministry of Industry and Trade of the Czech Republic, project number FR-T13/433 and also supported by the internal grant of TBU in Zlín No. IGA/FT/2014/003 funded from the resources of specific university research.

\section{References}

[1] JOHNSON, J. H., KIEPURA, R., HUMPHRIES, D. (1998) Engineered Materials Handbook, Vol. 1, Composites, ASM International, Ohio, pp. 52-154, ISBN 978-0871702791.

[2] HOEBERGEN, A., HOLMBERG, J. (2001). Vacuum infusion, ASM Handbook, 21, Composites, Materials Park (OH), p. 501-515, ISBN 978-0871707031.

[3] SUBA, O., SYKOROVA, L., LUKOVICS, I. (2012) Stress analysis of injection - moulded cylindrical parts reinforced with short fibres. Manufacturing technology. Vol 12, No. 13, pp. 251-254, ISSN 1213-2489.

[4] VALASEK, P., MULLER, M. (2012) Polymeric particle composites with filler saturated matrix. Manufacturing technology. Vol 12, No. 13, pp. 272-276, ISSN 1213-2489.

[5] MULLER, M., VALASEK, P. (2012) Abrasive wear effect on Polyethylene, Polyamide 6 and polymeric particle composites. Manufacturing technology. Vol 12, No. 13, pp. 55-59, ISSN 1213-2489.

[6] MULLER, M., STEFAN, P. (2011) Výzkum elektrické vodivosti u polymerních částicových kompozitů. Strojírenská technologie. roč. 16, č. 5, s. 12-18. ISSN 1211-4162.

[7] HOMOLA, P., KADLEC, M. (2011) Vyhodnocení rázového poškození uhlíkového kompozitu s termoplastovou matricí. Strojírenská technologie. roč. 16, č. 1, s. 11-15, ISSN 1211-4162.

[8] CORREIA, N.C., ROBITAILlE, F., LONG, A.C, RUDD, C.D., ŠIMÁČEK, P., ADVANI, S.G. (2005) Analysis of the vacuum infusion moulding process: I. Analytical formulation, Composites Part A: Applied Science and Manufacturing, Vol 36, No. 12, pp. 1645-1656, ISSN 1359-835X

[9] HAMMAMI A. (2001). Effect of reinforcement structure on compaction behavior in the vacuum infusion process, Polymer Compos., 22, pp. 337-48, ISSN 1548-0569

[10] RUSNAKOVA. S., ZALUDEK, M., BAKOSOVA, D. (2012) Processing engineering of large composites structures using low-pressure vacuum infusion. Manufacturing technology. Vol 12, No. 13, pp. 83-86, ISSN 1213-2489. 